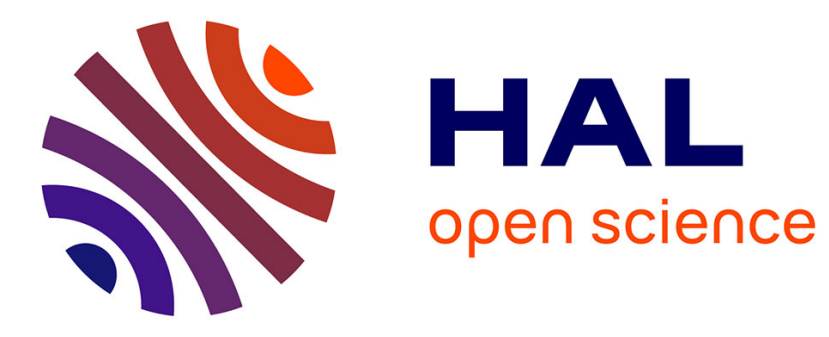

\title{
Serotonin type 4 receptor dimers
}

Sylvie Claeysen, Romain Donneger, Patrizia Giannoni, Florence Gaven, Lucie P. Pellissier

\section{To cite this version:}

Sylvie Claeysen, Romain Donneger, Patrizia Giannoni, Florence Gaven, Lucie P. Pellissier. Serotonin type 4 receptor dimers. Methods in Cell Biology - Receptor-Receptor Interactions, 117, Academic Press - Elsevier, pp.123-139, 2013, 117, 978-0-12-408143-7. 10.1016/B978-0-12-408143-7.00007-4 . hal-01792387

\section{HAL Id: hal-01792387 \\ https://hal.science/hal-01792387}

Submitted on 19 Feb 2020

HAL is a multi-disciplinary open access archive for the deposit and dissemination of scientific research documents, whether they are published or not. The documents may come from teaching and research institutions in France or abroad, or from public or private research centers.
L'archive ouverte pluridisciplinaire HAL, est destinée au dépôt et à la diffusion de documents scientifiques de niveau recherche, publiés ou non, émanant des établissements d'enseignement et de recherche français ou étrangers, des laboratoires publics ou privés. 
Running title: $5-\mathrm{HT}_{4}$ receptor dimers

\title{
Serotonin Type 4 Receptor Dimers
}

\author{
Sylvie Claeysen ${ }^{\text {a, b, c, }}$, Romain Donneger ${ }^{\text {a, b, c }}$, Patrizia Giannoni ${ }^{\text {a, b, c }}$, Florence Gaven ${ }^{\text {a, b, c }}$ and \\ Lucie P. Pellissier ${ }^{a, b, c}$
}

${ }^{a}$ CNRS, UMR-5203, Institut de Génomique Fonctionnelle, F-34000 Montpellier, France

${ }^{\mathrm{b}}$ Inserm, U661, F-34000 Montpellier, France

${ }^{\mathrm{c} U n i v e r s i t e ́ s ~ d e ~ M o n t p e l l i e r ~} 1$ \& 2, UMR-5203, F-34000 Montpellier, France

${ }^{*}$ Corresponding author: Sylvie Claeysen, Institut de Génomique Fonctionnelle, 141 Rue de la Cardonille, 34094 Montpellier Cedex 5, France. Phone: +33 4343592 15; Fax: +33 4675424 32; Email: sylvie.claeysen@igf.cnrs.fr

\begin{abstract}
Numerous class A G protein-coupled receptors and especially biogenic amine receptors have been reported to form homodimers. Indeed, the dimerization process might occur for all the metabotropic serotonergic receptors. Moreover, dimerization appears to be essential for the function of serotonin type $2 \mathrm{C}\left(5-\mathrm{HT}_{2} \mathrm{C}\right)$ and type $4\left(5-\mathrm{HT}_{4}\right)$ receptors and required to obtain full receptor activity. Several techniques have been developed to analyze dimer formation and properties. Due to our involvement in deciphering $5-\mathrm{HT}_{4} \mathrm{R}$ transduction mechanisms, we improved and set up new procedures to study 5$\mathrm{HT}_{4} \mathrm{R}$ dimers, by classical methods or modern tools. This chapter presents detailed protocols to detect 5-HT ${ }_{4} \mathrm{R}$ dimers by western blotting and co-immunoprecipitation, including the optimizations that we routinely carry out. We developed an innovative method to achieve functional visualization of 5-HT $\mathrm{H}_{4} \mathrm{R}$ dimers by immunofluorescence, taking advantage of the 5-HT 4 -RASSL (Receptor Activated Solely by
\end{abstract}


Synthetic Ligand) mutant that was engineered in the laboratory. Finally, we adapted the powerful Time-resolved FRET technology to assess a relative quantification of dimer formation and affinity.

Keywords: dimerization; oligomerization; GPCR; serotonin receptor; dimer visualization 


\section{Introduction}

Serotonin type 4 receptors $\left(5-\mathrm{HT}_{4} \mathrm{Rs}\right)$ belong to the extended family of serotonin receptors, which counts 15 different types of receptors involved in a wide range of physiological processes (Berger, Gray, \& Roth, 2009). All, except 5- $\mathrm{HT}_{3}$ receptor which is an ionic channel, are G protein-coupled receptors activating $\mathrm{G}_{\mathrm{s}^{-}}, \mathrm{G}_{\mathrm{i}}$ - or $\mathrm{G}_{\mathrm{q}^{-}}$-dependent pathways as well as $\mathrm{G}$ protein-independent signaling cascades (Barnes \& Sharp, 1999; Bockaert, Claeysen, Becamel, Dumuis, \& Marin, 2006; Millan, Marin, Bockaert, \& Mannoury la Cour, 2008). Homodimerization of serotonin receptors have been described for the 5- $\mathrm{HT}_{1 \mathrm{~A}}$ (Gorinski et al., 2012), 5- $\mathrm{HT}_{1 \mathrm{~B} / \mathrm{D}}$ (Lee et al., 2000), 5- $\mathrm{HT}_{2 \mathrm{~A}}$ (Lukasiewicz, Faron-Gorecka, Kedracka-Krok, \& Dziedzicka-Wasylewska, 2011), 5-HT2C (Herrick-Davis, Grinde, \& Mazurkiewicz, 2004), 5- $\mathrm{HT}_{4}$ (Berthouze et al., 2005) and 5-HT 7 (Renner et al., 2012), suggesting that all metabotropic serotonergic receptors form constitutive homodimers. This dimerization process is essential for receptor function. Indeed, the full activity of 5- $\mathrm{HT}_{2 \mathrm{C}}$ and $5-\mathrm{HT}_{4}$ receptors has been obtained with the binding of two molecules of ligand and one $\mathrm{G}$ protein per dimer (Herrick-Davis, Grinde, Harrigan, \& Mazurkiewicz, 2005; Pellissier et al., 2011).

Our team has been involved in the first pharmacological description of 5- $\mathrm{HT}_{4}$ receptors (Dumuis, Bouhelal, Sebben, Cory, \& Bockaert, 1988), in the cloning of some splice variants (Claeysen, Sebben, Becamel, Bockaert, \& Dumuis, 1999; Claeysen, Sebben, Journot, Bockaert, \& Dumuis, 1996) and in the characterization of several original signaling pathways following the activation of these receptors (Bockaert, Claeysen, Compan, \& Dumuis, 2011). For years, we have developped methods and tools to detect 5- $\mathrm{HT}_{4}$ receptor dimers that we present below. Ranging from classical to more sophisticated methods, we intend to provide here the hints and tips that facilitate $5-\mathrm{HT}_{4} \mathrm{R}$ dimerization study. We will describe the following procedures:

1. Cell transfection

2. Detection of $5-\mathrm{HT}_{4} \mathrm{R}$ dimers by western blot

3. Detection of $5-\mathrm{HT}_{4} \mathrm{R}$ dimers by co-immunoprecipitation

4. Analysis of $5-\mathrm{HT}_{4} \mathrm{R}$ dimers by immunofluorescence

5. Analysis of 5-HT $4 \mathrm{R}$ dimers by Time-Resolved Förster Resonance Energy Transfer (TRFRET). 


\section{Materials}

1. PBS: Phosphate-buffered saline, $\mathrm{pH} 7.4$, LONZA, DPBS-10X without $\mathrm{Ca}^{2+}$ and $\mathrm{Mg}^{2+}$, \#BE17$515 \mathrm{~F}$.

2. Trypsine EDTA solution 1X, Life Technologies, \#2530096

3. EP1X: electroporation mix composed of $50 \mathrm{mM} \mathrm{K}_{2} \mathrm{HPO}_{4}, 20 \mathrm{mM} \mathrm{CH}_{3} \mathrm{CO}_{2} \mathrm{~K}, 20 \mathrm{mM} \mathrm{KOH}$ and $26,7 \mathrm{mM} \mathrm{MgSO}_{4}$, in water. Adjust the $\mathrm{pH}$ to 7.4 with acetic acid.

4. $0.4 \mathrm{~cm}$ electroporation cuvettes, Eurogentec, \#CE-0004-50.

5. Falcon 100 or $150 \mathrm{~mm}$ cell culture dishes, cluster of 12,24 or 96 wells, $12 \mathrm{~mL}$ Falcon tubes (BD Biosciences).

6. Microtubes: $1.5 \mathrm{~mL}$ capacity.

7. DMEM-10\% dFBS: DMEM (DMEM 4.5g/L Glucose with L-Glutamine, LONZA, \#BE12604F) supplemented with 10\% dialyzed fetal bovine serum (Lonza, \#14-810F).

8. Myc-tagged and HA-tagged 5-HT 4 receptors cDNA in plasmid suitable for expression in mammalian cells (e. g. pRK5 or pcDNA3.1). Epitopes are located at the N-terminus of the receptor. The signal peptide (SP) from the metabotropic glutamate receptor type 5 is added before HA-tag whereas no SP is necessary with Myc-tag.

9. Empty plasmid cDNA used as carrier and control (e. g. pRK5 or pcDNA3.1).

10. Rubber policeman: 34mm wide rubber scrapper "Model K" on Saint-Gobain, Verneret Plastic catalog, \#V101029, ROGO-SAMPAIC (France) or AUXILAB S.L (Spain).

11. Potter homogenizer: $1 \mathrm{~mL}$ capacity PYREX® Potter tissue homogenizer, Corning, \#7725T-1.

12. Protease inhibitors: cOmplete, EDTA-free Protease Inhibitor Cocktail Tablets, Roche Applied Science, \#04693132001.

13. Tris-Lysis Buffer: $10 \mathrm{mM}$ Tris- $\mathrm{HCl}, \mathrm{pH}=7.4 ; 2 \mathrm{mM}$ EDTA; protease inhibitors.

14. Bradford reagent: Quick Start Bradford 1x Dye Reagent, Biorad, \#500-0205.

15. Solubilization Buffer: $50 \mathrm{mM}$ NaHPO4/NaH2PO4, $\mathrm{pH}=7.2 ; 1 \mathrm{mM}$ EDTA; $1 \%$ SDS or 10 mM CHAPS; protease inhibitors.

16. Deglycosylation Buffer: $50 \mathrm{mM}$ NaHPO4/NaH2PO4, $\mathrm{pH}=7.2 ; 10 \mathrm{mM}$ EDTA; $1 \%$ SDS or 10 mM CHAPS; protease inhibitors. 
17. N-glycosydase F: PNGaseF, New England Biolabs, \#P0704S.

18. Laemmli Buffer 4X: $200 \mathrm{mM}$ Tris/HCl, $\mathrm{pH}=6.8 ; 8 \%$ SDS; $40 \%$ glycerol; $20 \% \beta$ mercaptoethanol; bromophenol blue.

19. TBST: TBS (20 mM Tris/HCl, $\mathrm{pH}=7.4 ; 150 \mathrm{mM} \mathrm{NaCl}) ; 0.25 \%$ Tween-20.

20. TBST-milk: TBST, 5\% milk.

21. TBST-BSA: TBST, 5\% BSA (Albumin from bovine serum, Sigma, \#A2153)

22. Ms anti-Myc antibody: Mouse anti-c-Myc antibody, Sigma Aldrich 9E10, \#M4439.

23. Rb anti-Myc antibody: Rabbit anti-c-Myc antibody, Santa Cruz Biotechnology, sc789, \#D1008.

24. Ms anti-HA antibody: Mouse anti-HA antibody, Covance, MMS-101P, \#E11AF0013.

25. $\mathrm{Rb}$ anti-HA antibody: Rabbit anti-HA antibody, Life technologies, \#71-5500.

26. Anti-mouse antibody conjugated with HRP: ECL Mouse IgG, HRP-linked whole A $\beta$, GE Healthcare; \#NA931.

27. GAR-red: Alexa Fluor ${ }^{\circledR} 594$ Goat Anti-Rabbit IgG, Life Technologies, \#A-11012

28. GAM-green: Alexa Fluor ${ }^{\circledR} 488$ Goat Anti-Mouse IgG, Life Technologies, \#A-11001

29. Pierce ECL Western Blotting Substrate: Thermo Scientific, \#32209.

30. DSP: Dithiobis[succinimidyl propionate], Thermo Scientific, \#22586. Fist dilution of DSP at $25 \mathrm{mM}$ in DMSO, then final dilution at $1.25 \mathrm{mM}$ in PBS.

31. Phosphatase inhibitors: $10 \mathrm{mM} \mathrm{NaF} ; 2 \mathrm{mM} \mathrm{Na}^{+}$vanadate; $1 \mathrm{mM} \mathrm{Na}{ }^{+}$pyrophosphate.

32. DDM: n-Dodecyl $\beta$-D-maltoside, Sigma, \#D5172.

33. DDM-Lysis Buffer: for $10 \mathrm{ml}$ of buffer, $40 \mathrm{mg}$ of DDM, $20 \mathrm{mM}$ HEPES, $150 \mathrm{mM} \mathrm{NaCl}, 1 \%$ NP40, 10\% Glycerol, phosphatase inhibitors, half a tablet of protease inhibitors, ajust the volume with water.

34. Anti-HA/agarose beads: Mouse anti-HA-tag monoclonal antibody, agarose-conjugated, Sigma, \#DMAB8895.

35. Glass slides and coverslips $(\varnothing 18 \mathrm{~mm})$.

36. PORN 1X: Poly-L-ornithine hydrobromide (10 mg/L in PBS), Sigma, \#P3655. 
37. PFA: Paraformaldehyde 16\% in water, Euromedex, \#RT 15710-S.

38. PBS-Glycine: PBS, 0.1M Glycine (Sigma, \#G7126).

39. PBS-Triton: PBS, $0.05 \%$ Triton X-100 (Sigma, \#T8532).

40. PBS-Gelatin: PBS, 0.2\% Gelatin (Sigma, \#G9391).

41. 5-HT: 5-Hydroxytryptamine (Serotonin creatinine sulfate monohydrate, Sigma, \#H7752)

42. BIMU 8: 2,3-Dihydro-N-[(3-endo)-8-methyl-8--azabicyclo[3.2.1]oct-3-yl]-3-(1-methylethyl)2-oxo--1H-benzimidazole-1-carboxamide hydrochloride, Tocris Bioscience, \#4374.

43. VECTASHIELD: VECTASHIELD Mounting Medium, Vector Laboratories, \#H-1000.

44. HBS: $20 \mathrm{mM}$ HEPES, $150 \mathrm{mM} \mathrm{NaCl}, 4.2 \mathrm{mM} \mathrm{KCl}, 0.9 \mathrm{mM} \mathrm{CaCl} 2,0.5 \mathrm{mM} \mathrm{MgCl} 2,0.1 \%$ glucose, $0.1 \%$ BSA.

45. HBS-KF: HSB, 200mM KF.

46. Anti HA-K: Eu ${ }^{3+}$ Cryptate-conjugated mouse monoclonal antibody anti-HA, Cisbio Bioassays, \# 610HAKLA.

47. Anti HA-d2: d2-conjugated mouse monoclonal antibody anti-HA, Cisbio Bioassays, \# 610HADAA.

48. Anti FLAG M2-K: Eu ${ }^{3+}$ Cryptate-conjugated mouse monoclonal antibody anti-FLAG, Cisbio Bioassays, \# 61FG2KLA.

49. Anti FLAG M2-d2: d2-conjugated mouse monoclonal antibody anti-FLAG, Cisbio Bioassays, \# 61FG2DLA.

\section{Methods}

\section{A. Cell transfection}

Our protocols are based on transient transfection of COS-7 cells or HEK293 cells by electroporation as described in (Claeysen et al., 1996). Wash cells at 70\% confluence once in PBS, trypsinize them and, after centrifugation, resuspend them in EP1X buffer with 25-500 ng of epitope-tagged receptor cDNA and $15 \mu \mathrm{g}$ empty plasmid that acts as carrier. Transfer $300 \mu \mathrm{L}$ of cell suspension $\left(10^{7}\right.$ cells $)$ to a $0.4 \mathrm{~cm}$ electroporation cuvette and pulse the cells using a Gene pulser apparatus (settings: $950 \mu \mathrm{F}$ and 
280 V or 270 V for COS-7 or HEK293, respectively). Quickly after the shock, dilute cells in DMEM $\left(10^{7}\right.$ cells $/ \mathrm{mL}$ ) containing $10 \%$ dialyzed fetal bovine serum (dFBS) and plate them on 100 or $150 \mathrm{~mm}$ Falcon cell culture dishes or into appropriated clusters. 24h post-transfection process the cells to study $5-\mathrm{HT}_{4} \mathrm{R}$ dimers.

\section{B. Detection of 5-HT 4 R dimers by western blot}

Dimerisation of $5-\mathrm{HT}_{4}$ receptors can be evaluated by western blotting in denaturating conditions. Indeed $5-\mathrm{HT}_{4} \mathrm{R}$ dimers form with high affinity and resist to detergents. Four mouse splice variants of the 5- $\mathrm{HT}_{4}$ receptor have been described that differ in length and composition of their C-terminus: 5-

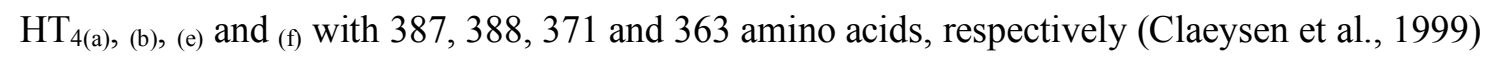
(Figure 1A). We used the difference in length of these variants to show that they can interact with each other. We also used a truncated 5- $\mathrm{HT}_{4}$ receptor at the residue $327: \Delta 327$ that is devoid of the $\mathrm{C}$ terminus of the receptor (Figure 1A).

\section{Cell lysate and membrane preparation}

Dimerization of 5- $\mathrm{HT}_{4}$ receptors is analyzed on membrane receptor preparations. Plate four electroporations of COS-7 cells ( 4 x $10^{7}$ cells) in two $150 \mathrm{~mm}$ Falcon dishes, for each condition. Use $500 \mathrm{ng}$ of Myc-tagged 5-HT ${ }_{4} \mathrm{R}$ cDNA per $10^{7}$ cells in single transfection assays and $250 \mathrm{ng}$ of each receptor per $10^{7}$ cells in cotransfection experiments. $24 \mathrm{~h}$ post-transfection, wash the cells with icecold PBS, then add $5 \mathrm{~mL}$ of cold PBS per 150-mm plate and scrape the cells on ice with a rubber policeman. Transfer the content of two dishes in one $12 \mathrm{~mL}$ Falcon tube. After centrifugation for 5 min at 2,400 g and at $4{ }^{\circ} \mathrm{C}$, resuspend each cell pellet in $500 \mu \mathrm{L}$ of Tris-Lysis Buffer and transfer in 1 $\mathrm{mL}$ capacity Potter homogenizer. After 20 up and down regular and gentle moves of the pestle in the glass mortar, transfer the cell homogenates in $1.5 \mathrm{~mL}$ microtubes and pellet the membranes by 20 -min centrifugation at $43,000 \mathrm{~g}$ and at $4^{\circ} \mathrm{C}$. Resuspend the membrane pellet in $200 \mu \mathrm{L}$ of Tris-Lysis Buffer and quantify the protein levels (Bradford reagent) twice with $5 \mu \mathrm{L}$ of sample. Aliquot the membrane preparations (200 $\mu \mathrm{g} /$ aliquot), freeze in liquid nitrogen and store at $-80^{\circ} \mathrm{C}$ for further use. 
Solubilization and deglycosylation of the samples

In transfected cells, 5- $\mathrm{HT}_{4}$ receptors exist in many glycosylated forms resulting in smear bands on SDS-page electrophoresis. To circumvent this problem we add a deglycosylation step of the receptor preparation prior to gel electrophoresis.

Thaw and pellet $400 \mu \mathrm{g}$ of each sample by 20 -min centrifugation at $43,000 \mathrm{~g}$ and at $4{ }^{\circ} \mathrm{C}$. To solubilize the membrane proteins, resuspend the pellet in $200 \mu \mathrm{L}$ of Solubilization Buffer and incubate $2 \mathrm{~h}$ on a rotating wheel in a cold room at $4^{\circ} \mathrm{C}$. Then, pellet the remaining cell fragments by 20 -min centrifugation at $43,000 \mathrm{~g}$ at $4{ }^{\circ} \mathrm{C}$ and collect the supernatant. Adjust the EDTA concentration in the sample buffer to increase it to 10 mM EDTA (Deglycosylation Buffer), add $2 \mu \mathrm{L}$ (1000 units) of Nglycosydase $\mathrm{F}$ and incubate the tubes overnight at $37^{\circ} \mathrm{C}$. After adding $67 \mu 1$ of Laemmli Buffer $4 \mathrm{X}$ to the sample, load $25 \mu \mathrm{g}$ of proteins of each sample on an acrylamide gel.

\section{Western blot and detection of the 5- $\mathrm{HT}_{4}$ receptor dimers}

Load the samples on Tris/ $\mathrm{HCl}$ gels ( $8 \%$ or $10 \%$ acrylamide/bis-acrylamide) in denaturing conditions (SDS). To achieve a good separation of the different dimer bands, use 20-cm glass plate systems (Settings: stacking, $1 \mathrm{~h}$ at $100 \mathrm{~V}$, Separation $5 \mathrm{~h}$ at 200V). Transfer the proteins on nitrocellulose using wet-electrophoretic system (Settings: $30 \mathrm{~V}$, over-night at $4^{\circ} \mathrm{C}$ ). After transfer, saturate the nitrocellulose membrane for $1 \mathrm{~h}$ in TBST-milk, then rinse it with TBST and incubate overnight with the anti-Myc antibody diluted $1 / 1000$ in TBST-milk, under gentle agitation at $4{ }^{\circ} \mathrm{C}$. Wash the membrane six times, 5 min, in TBST, then incubate it for $1 \mathrm{~h}$ with the secondary antibody (e. g. antimouse antibody conjugated with HRP, 1/4000) diluted in TBST-milk, under gentle agitation at room temperature. Wash the membrane six times, $5 \mathrm{~min}$, in TBST, then reveal the bands using a chemiluminescent kit according to manufacturer instructions (e. g. Pierce ECL Western Blotting Substrate)

Using this technique we are capable to detect monomers and dimers form for each 5- $\mathrm{HT}_{4}$ receptor variant (Figure 1A). By co-transfection of a "long" variant with a "short" one e. g. Variant (a) with variant (e), we can discriminate the dimer formation of (a) and (e) protomers (Figure 1B). 5-HT 4 
receptor dimers can also be detected using a receptor devoid of its C-terminal domain (Figure 1C) and this truncated receptor is capable to associate with (a) or (b) variants (Figure 1D).

To resume, the key steps in this technique are 1) to start with a membrane preparation of proteins, 2) to apply a deglycosylation step to the samples and 3) to use long-separation gels.

\section{Detection of 5-HT 4 R dimers by co-immunoprecipitation}

Co-immunoprecipitation is a classical technique to demonstrate interactions between proteins. We describe below our protocol to co-immunoprecipitate 5- $\mathrm{HT}_{4}$ receptors.

Transfect $10^{7}$ HEK293 cells with Myc-tagged and HA-tagged 5-HT 4 receptors, alone or in combination (500 ng and $300 \mathrm{ng}$ of each construct, respectively, as HA-tagged receptor are expressed more easily) and seed the cells in $150 \mathrm{~mm}$ Falcon petri dish in DMEM-10\% dFBS. 24 h posttransfection, apply $15-20 \mathrm{~mL}$ of the cross-linking agent DSP in PBS for $30 \mathrm{~min}$ at $37^{\circ} \mathrm{C}$. Stop the reaction by washing the cells twice with PBS. Then, add $1 \mathrm{~mL}$ of DDM-Lysis Buffer per dish and scrape the cells on ice using a rubber policeman. Collect cell lysates in microtubes. Incubate samples for $1 \mathrm{~h}$ at $4{ }^{\circ} \mathrm{C}$ on a rotating wheel. Centrifuge the samples at $20.000 \mathrm{~g}$ for $15 \mathrm{~min}$ at $4^{\circ} \mathrm{C}$ and keep the supernatants containing solubilized proteins. Quantify the protein concentration (e. g. Bradford reagent). $1 \mathrm{mg}$ of solubilized proteins should then be incubated overnight at $4{ }^{\circ} \mathrm{C}$ with anti-HA/agarose beads on a rotating wheel. Centrifuge at $5.000 \mathrm{~g}$ for $1 \mathrm{~min}$ at $4^{\circ} \mathrm{C}$ to pellet the beads and remove the supernatant. Wash the beads 3 times using $1 \mathrm{~mL}$ of DDM-Lysis Buffer. Resuspend the beads in $40 \mu \mathrm{L}$ of Laemmli Buffer 1X to elute the immunoprecipitated proteins. Load $40 \mu \mathrm{L}$ of each sample on $12 \%$ acrylamide/bis-acrylamide gels, resolve proteins by classical SDS-PAGE gel electrophoresis and detect them by western blotting (e. g. use Mini-Protean and Trans-Blot SD Semi-Dry Transfer Cell, Biorad). The immunoblotting protocol described above is used for detection of the receptor bands. Anti-Myc or anti-HA antibodies are diluted in diluted TBST-BSA at 1/1000 (Ms Anti-Myc), 1/400 (Rb Anti-Myc) or 1/500 (Ms Anti-HA), respectively. Typical results obtained using this protocol have been shown in (Pellissier et al., 2011). 


\section{Analysis of $5-H_{4} \mathrm{R}$ dimers by immunofluorescence}

The pharmacological properties of the $\mathrm{D}^{100} \mathrm{~A}-5-\mathrm{HT}_{4}$ mutant receptors $\left(\mathrm{D}^{100} \mathrm{~A}\right)$ constitute a great advantage to visualize 5- $\mathrm{HT}_{4} \mathrm{R}$ dimers by immunofluorescence. The Asp 100 in 5- $\mathrm{HT}_{4} \mathrm{R}$ transmembrane domain 3 ( $\mathrm{D}^{3.32}$ in Ballesteros-Weinstein nomenclature (Ballesteros \& Weinstein, 1995)) corresponds to an aspartate residue that is well conserved in GPCRs responding to biogenic amines and involved in their binding site (Strader et al., 1991). $\mathrm{D}^{100} \mathrm{~A}$ point mutation suppresses the lateral side chain of this aspartate and, consequently, serotonin is unable to bind and activate the mutated 5- $\mathrm{HT}_{4}$ receptor (Figure 1B) (Claeysen, Joubert, Sebben, Bockaert, \& Dumuis, 2003). However, this receptor remains fully activable by highly selective 5- $\mathrm{HT}_{4} \mathrm{R}$ synthetic agonists, such as BIMU 8 (Figure 1B), thus belonging to the RASSL family (Receptor Activated Solely by Synthetic Ligands) (Conklin et al., 2008). 5-HT4 receptors are rapidly desensitized and internalized by endocytosis after activation by an agonist. Upon 5-HT exposure, $\mathrm{D}^{100} \mathrm{~A}-5-\mathrm{HT}_{4}$ receptors stay at the plasma membrane, whereas wild type (WT) 5- $\mathrm{HT}_{4}$ receptors enter inside the cell. However, if we form dimers between $\mathrm{WT}$ and $\mathrm{D}^{100} \mathrm{~A}$ protomers, these molecular complexes can undergo endocytosis, providing a way to separate and to visualize $\mathrm{D}^{100} \mathrm{~A}$ dimers from the other populations of $5-\mathrm{HT}_{4}$ receptors expressed in the cell.

Prior to cell transfection, place glass coverslips in 12 wells-clusters and incubate them with 300 $\mu \mathrm{L} /$ well of PORN $1 \mathrm{X}$ for minimum $30 \mathrm{~min}$ at $37^{\circ} \mathrm{C}$. Wash the slides twice with $1 \mathrm{~mL}$ PBS before seeding the cells. Transfect HEK297 cells ( $10^{7}$ cells) with $300 \mathrm{ng}$ of HA- or Myc-tagged 5-HT 4 receptors, alone or in combination. Resuspend them in $20 \mathrm{~mL}$ of DMEM-FBSd and plate $1 \mathrm{~mL} / \mathrm{well}$ (500 000 cell/well). $24 \mathrm{~h}$ later, replace the cell culture medium by DMEM alone. $48 \mathrm{~h}$ posttransfection, place the clusters at $4^{\circ} \mathrm{C}$ in a cold room for $15 \mathrm{~min}$. Remove the medium and incubate for $90 \mathrm{~min}$ at $4^{\circ} \mathrm{C}$ with the $500 \mu \mathrm{L}$ of the primary antibodies (Rb anti-HA, 1/300 and/or Ms anti-Myc, 1/400) diluted in cold DMEM. Wash twice with cold DMEM. Place the clusters back at $37^{\circ} \mathrm{C}$ in the cell culture incubator under routine parameters for $15 \mathrm{~min}$. Remove cell medium and add $1 \mathrm{~mL}$ of stimulation medium (5-HT or BIMU8, $10^{-5} \mathrm{M}$ in DMEM) or DMEM alone as control for $30 \mathrm{~min}$ at $37^{\circ} \mathrm{C}$. Add $145 \mu \mathrm{L}$ of PFA $16 \%$ in each well ( $2 \%$ final concentration) and fix the cells $10 \mathrm{~min}$ at $37^{\circ} \mathrm{C}$. Wash the cells 3 times for $10 \mathrm{~min}$ at room temperature with PBS-Glycine. Then, permeabilize the cell 
with $500 \mu \mathrm{L}$ of PBS-Triton for $5 \mathrm{~min}$ at room temperature. Wash 3 times for 5, 10, then 15 min with PBS-Gelatin and incubate with secondary antibodies coupled to fluorophores (e. g. GAR-red, 1/1000 and GAM-green, 1/1000) for $1 \mathrm{~h}$ at room temperature in the dark. Wash 3 times for 5, 10, then 15 min with PBS, then mount the coverslips on glass slide using VECTASHIELD. Image the samples using a confocal microscope. A typical experiment is presented in Figure 4.

Under basal conditions, WT-5-HT $\mathrm{HT}_{4}$ receptors as well as $\mathrm{D}^{100} \mathrm{~A}-5-\mathrm{HT}_{4}$ receptors expressed alone or coexpressed were predominantly located at the cell surface (Fig. 3A, D, G, J, M). A marginal constitutive internalization, reflecting the constitutive activity of $5-\mathrm{HT}_{4}$ receptors, was detected for both WT and mutant receptors (for example some dotted labeling in Fig. 3A). Upon activation with an agonist (5-HT or BIMU8), the WT-5-HT 4 receptors were internalized as shown by both an internal dotted labeling and a decrease in cell surface labeling (Fig. 3B, C). In the presence of 5-HT, the $\mathrm{D}^{100} \mathrm{~A}$ mutant remained at the cell surface (Fig. 3E), whereas it internalized in the presence of BIMU8 (Fig. $3 \mathrm{~F})$. However, 5-HT which does not bind to $\mathrm{D}^{100} \mathrm{~A}$, induced an internalization of this mutant receptor, when the $\mathrm{D}^{100} \mathrm{~A}$ mutant was co-expressed with WT receptor (Fig. 3K, 3N). Indeed, 5-HT induced the internalization of WT/WT dimers, (Fig. 3H and Fig. 3N, red dots) as well of WT/D $\mathrm{D}^{100} \mathrm{~A}$ dimers (Fig. $3 \mathrm{H}$, $\mathrm{K}$ and fig. $3 \mathrm{~N}$, yellow dots) whereas $\mathrm{D}^{100} \mathrm{~A} / \mathrm{D}^{100} \mathrm{~A}$ dimers remained at the cell surface (Fig. $3 \mathrm{~K}$ and Fig. 3N, green dots). All types of complexes internalized after a 30 min-exposure with BIMU8 (Fig. 3I, $\mathrm{L}, \mathrm{O})$. The simplest explanation of these results implicates the existence of a $\mathrm{WT} / \mathrm{D}^{100} \mathrm{~A}$ dimer. When the WT monomer of the WT/ $\mathrm{D}^{100} \mathrm{~A}$ dimer was occupied by $5-\mathrm{HT}$, both WT and $\mathrm{D}^{100} \mathrm{~A}$ protomers were internalized.

\section{E. Analysis of 5-HT 4 R dimers by TR-FRET}

TR-FRET technology provides an easy way to detect the existence of 5-HT 4 dimers and to examine their propensity to form heterodimers with other GPCRs.

Transfect COS-7 cells with the appropriate plasmids (N-terminally tagged with HA or FLAG epitopes) and seed them in 96-well plates (100 000 cells/well). Prepare 12 wells per condition. $24 \mathrm{~h}$ after transfection, wash the cells with HBS and incubate them at $4^{\circ} \mathrm{C}$ for 24 hours with the appropriate fluorescent anti-FLAG or -HA antibodies diluted in HBS-KF (KF is added to avoid quenching of 
europium cryptate). In half of the wells, add $50 \mu \mathrm{L}$ of $4 \mathrm{nM}$ Anti-FLAG M2-K and $50 \mu \mathrm{L}$ of $10 \mathrm{nM}$ Anti-HA-d2. In the other half of the wells, add $50 \mu \mathrm{L}$ of $4 \mathrm{nM}$ Anti-FLAG M2-K and $50 \mu \mathrm{L}$ of HBSKF. Quantification of FRET signals is performed by Homogenous Time Resolved Fluorescence $\left(\mathrm{HTRF}^{\circledR}\right)$ settings (Maurel et al., 2004) on appropriate apparatus (see http://www.htrf.com/readers for compatible readers). Express the results as the specific signal over background, Delta F, as described in (Maurel et al., 2004).

Figure 5 presents the different type of experiments that can be routinely performed using this simple and convenient technology. HA or FLAG-tagged $\mathrm{GB}_{1}$ and $\mathrm{GB}_{2} \mathrm{GABA}_{\mathrm{B}}$ receptor subunits are classically used as positive controls of constitutive dimerization. You have to verify that $5-\mathrm{HT}_{4}$ and $\mathrm{GABA}_{\mathrm{B}}$ receptors are expressed at the cell surface in similar amounts by ELISA quantification for example (Fig. 4A). In these conditions the TR-FRET signal detected when we co-express HA- and FLAG-5-HT 4 R (Fig. 4B) represents only $30 \%$ of the signal obtained for GABA ${ }_{B} R$ heterodimers. Indeed, $\mathrm{GABA}_{\mathrm{B}}$ receptors expressed at the cell surface are obligatory heterodimers, whereas HA-5$\mathrm{HT}_{4} \mathrm{R}$ monomers could associate with either HA-5-HT 4 or FLAG-5-HT 4 receptors. Therefore, HA-5$\mathrm{HT}_{4} \mathrm{R} / \mathrm{FLAG}-5-\mathrm{HT}_{4} \mathrm{R}$ dimers, which are the only couples producing FRET, represent only half of the real amount of dimers at the cell surface. Thus, the real signal for $5-\mathrm{HT}_{4} \mathrm{R}$ dimers can be assumed to be around $60 \%$ of the $\mathrm{GABA}_{\mathrm{B}} \mathrm{R}$ FRET signal.

By maintaining a constant density of $\mathrm{HA}-5-\mathrm{HT}_{4} \mathrm{Rs}$ (donors, use Anti HA-K antibodies) and increasing the density of FLAG-5-HT 4 R or FLAG-GB 2 (acceptors, use Anti Flag M2-d2), saturating FRET curves are obtained for WT 5- $\mathrm{HT}_{4}$ receptor, whereas the signal between $5-\mathrm{HT}_{4} \mathrm{R}$ and $\mathrm{GB}_{2}$ is linear and unsaturable (Fig. 4C). These type of results indicate that $5-\mathrm{HT}_{4} \mathrm{R}$ dimerization is specific, whereas the low $5-\mathrm{HT}_{4} \mathrm{R} / \mathrm{GB}_{2}$ signal reflects a collisional and non-specific contact.

Competitions experiments can also be performed to assess specificity of $5-\mathrm{HT}_{4} \mathrm{R}$ dimerization. Coexpress constant amounts of HA- and FLAG-5-HT 4 R with increasing amounts of competing GPCRs, N-terminally tagged with Myc epitope: GABA ${ }_{B 2} \mathrm{R}$, serotonin type 7 receptor $\left(5-\mathrm{HT}_{7} \mathrm{R}\right)$ or $\beta_{2}$ adrenergic receptor ( $\left.\beta_{2}-\mathrm{AR}\right)$, in Figure 5D. As shown by its corresponding horizontal data-fitting line, $\mathrm{GABA}_{\mathrm{B} 2} \mathrm{R}\left(\mathrm{GB}_{2}\right)$ is unable to compete with 5-HT4 $\mathrm{R}$ dimerization (Fig. 4D). 5- $\mathrm{HT}_{7}$ receptors compete with the formation of 5- $\mathrm{HT}_{4} \mathrm{R}$ homodimers at relatively high and probably not physiological 
concentrations. Interestingly, Myc- $\beta_{2}-$ AR strongly reduces the FRET signal as efficiently as Myc-5$\mathrm{HT}_{4} \mathrm{R}$ and competed with HA- and FLAG-5-HT $\mathrm{H}_{4}$ receptors for dimer formation, indicating the possible existence of heterodimers between 5- $\mathrm{HT}_{4}$ and $\beta_{2}$-adrenergic receptors.

\section{Discussion}

In this chapter, we first described protocols that are classically used in biochemistry of GPCRs such as western blotting and co-immunoprecipitation. This part is important for us, as detecting $5-\mathrm{HT}_{4}$ receptors on gel from transient expression in cell lines is a tricky point. Indeed, when this receptor is overexpressed it appears in numerous bands, corresponding to different glycosylation states and maturation. The receptors populations that have reached the plasma membrane are more homogenous in term of sugar maturation, thus starting from a membrane preparation improve the results. One alternative could be to use kits to purify membrane proteins such as Qproteome Plasma Membrane Protein Kit (Qiagen, \#37601), which gives good results in our hands, is less time-consuming but more expensive. Adding a deglycosylation step was also a plus to clarify the migration profile of $5-\mathrm{HT}_{4}$ receptors. The challenge was to find a replacement to the N-Glycosidase F from Roche that was discontinued. This enzyme was efficient in numerous buffers and the actual replacement enzymes (Peptide-N-Glycosidase F, PNGase F) from different suppliers are not as effective. Migration on long gels is another trick to separate more easily complexes of similar size that helps us to show the possibility of heteromerisation between $5-\mathrm{HT}_{4} \mathrm{R}$ splice variants.

We then described a method to functionally assess the formation of dimers by cross desensitization of the RASSL-5-HT 4 mutant that is unable to bind 5-HT (Claeysen et al., 2003). In the presence of WT 5- $\mathrm{HT}_{4}$ receptor and upon 5-HT exposure, the $\mathrm{D}^{100} \mathrm{~A}$ mutant is co-internalized with the WT receptor, thus providing a nice way to show $\mathrm{D}^{100} \mathrm{~A} / \mathrm{WT}$ dimers. A key step in this procedure is to incubate the cells with the primary antibodies prior to fixation. This procedure avoids the small permeabilization that could be induced by paraformaldehyde. Antibodies in contact with intact cells will label only plasma membrane receptors and not receptors that are in the synthesis pathway. Consequently, the 
dimers that are immunolabelled and endocyted originate without doubt from the plasma membrane.

Interestingly, our cross desensitization assay using the $\mathrm{D}^{100} \mathrm{~A}$ mutant and the WT 5- $\mathrm{HT}_{4}$ receptor could also be used to assess whether a particular 5- $\mathrm{HT}_{4}$ mutant named " $\mathrm{M}$ " is able to dimerize or not. If the M mutant that has to be tested retains a classic internalization profile upon 5-HT exposure, it will be co-expressed with the $\mathrm{D}^{100} \mathrm{~A}$ mutant. Upon 5-HT exposure, if RASSL protomers appear to be internalized, one can conclude that the $\mathrm{M}$ mutant is capable to dimerize with the $\mathrm{D}^{100} \mathrm{~A}$ protomers. This technique could thus be used as a dimerization-screening test. $5-\mathrm{HT}_{4}$ mutants that have been described to disrupt dimer formation (Berthouze et al., 2007) has to be assayed in our procedure to validate this hypothesis. Moreover, due to the high conservation of an aspartate in the third transmembrane domain of biogenic amine receptors (Strader et al., 1991), corresponding to the $\mathrm{D}^{100}$ or $\mathrm{D}^{3.32}$ position, the point mutation into alanine can easily be transposed in metabotropic serotoninergic receptors (Kristiansen et al., 2000) as well as other class A GPCR such as melanocortin-4 receptors (Srinivasan, Santiago, Lubrano, Vaisse, \& Conklin, 2007) or histamine H1 receptors (Bakker et al., 2004) conferring similar RASSL properties to the mutated receptors. Consequently, this dimerizationscreening test could be extended to other GPCR structurally related to the 5- $\mathrm{HT}_{4}$ receptors.

We finally described a protocol to achieve relative quantification of 5- $\mathrm{HT}_{4} \mathrm{R}$ dimer formation using TR-FRET. Using this method we can also assess heteromerization with other GPCRs by competition assay. This technology is simple and reliable and can be improved using covalent binding of the acceptor and donor fluorophores to a small suicide-enzyme inserted N-terminally in the GPCRs instead of the classical tags (Comps-Agrar et al., 2011). Future developments will aim to use permeant substrates of these enzymes to provide intracellular labeling of the dimers and follow their trafficking.

\section{Summary}

Dimerization process is essential for $5-\mathrm{HT}_{4}$ receptor function. We provide here methods to analyze 5$\mathrm{HT}_{4} \mathrm{R}$ dimer formation ranging from classical western blotting and co-immunoprecipitation protocols to cross-internalization screening assay and TR-FRET measurements. We intend to describe in details the experimental procedures with the key points necessary to achieve precise and accurate studies regarding $5-\mathrm{HT}_{4}$ receptor dimerization. 


\section{Aknowledgements}

This work was supported by grants from Centre National de la Recherche Scientifique (CNRS);

Institut National de la Santé et de la Recherche Médicale (INSERM); Ministère Français de la Recherche (ANR Blanc-2006-0087-02 - "GPCR dimers"); Université de Montpellier.

cAMP quantification, FRET measurements and ELISA were carried out using the ARPEGE

Pharmacology Screening Interactome facility at the Institute of Functional Genomics (Montpellier, France) 


\section{Figure Legends}

Figure 1: Mouse 5-HT 4 variants and key mutants receptors used.

A) Scheme of the mouse 5- $\mathrm{HT}_{4}$ receptor showing the four splice variants differing in length and composition after a common splicing site (vertical bar). Position of $\Delta 327$ mutant, devoid of the Cterminal domain of the receptor, is depicted by a double-head arrow. $\mathrm{D}^{100} \mathrm{~A}$ mutation is indicated with a dark-blue plain circle. B) Pharmacological profile of the wild-type 5- $\mathrm{HT}_{4}$ receptor (WT) and of the $\mathrm{D}^{100} \mathrm{~A}$ mutant. Both receptors are activated by the full agonist BIMU8, whereas only the WT receptor is capable to respond to the endogenous ligand serotonin (5-HT). 5-HT is unable to bind into $\mathrm{D}^{100} \mathrm{~A}$ mutant.

\section{Figure 2: Analysis of 5-HT 4 receptor dimers by western blot.}

All receptors used, N-terminally tagged with c-Myc epitope, have been transiently expressed in COS-7 cells and processed as described in the main text. Transfected variant or mutant receptors are indicated above the blots. A) Transfection of each variant separately show the formation of dimers and monomers of (a), (b), (e) or (f) variants. B) When variants (a) and (e) are co-transfected (right line), a band of an intermediate size between (a) and (e) homodimer bands appears that corresponds to the formation of a dimer between (a) and (e) protomers (indicated with an asterisk). C) Transfection of the $\Delta 327$ mutant devoid of its C-terminal domain shows the presence of monomers, dimers and higher molecular species with a size compatible with "trimers". D) Co-transfections of $\Delta 327$ and (a) or (b) receptors shows the capability of $\Delta 327$ mutant to interact with (a) or (b) variant by the presence of an intermediate size band between $\Delta 327$ and (a) or (b) dimer bands corresponding to a dimer composed of $\Delta 327$ and (a) or (b) protomers (indicated with an asterisk). Legend: Plain triangles, monomers of "long" variants (a) and (b); open triangles, monomers of "short" variants (e) and (e); double-triangles, dimers of "long" variants (plain) or "short" variants (open); arrows, monomers of $\Delta 327$ mutant; double-arrows, $\Delta 327$ dimers; triple-arrows, $\Delta 327$ "trimers"; NS, non-specific band. 


\section{Figure 3: Functional evidence of 5-HT 4 R dimerization at the cell surface.}

Myc-5-HT 4 R WT (in red, A, B, C), RhoTag-5-HT 4 R-D ${ }^{100} \mathrm{~A}$ (in green, D, E, F), or both (G-O) were transiently expressed in HEK-293 cells and visualized by immunofluorescence confocal microscopy. Cells are fixed in basal conditions $(\mathbf{A}, \mathbf{D}, \mathbf{G}, \mathbf{J}, \mathbf{M})$ or after a 30 min-exposure with $10 \mu \mathrm{M}$ of either 5-HT (B, E, H, K, N) or BIMU8 (C, F, I, L, O).

\section{Figure 4: Study of 5-HT ${ }_{4} \mathrm{R}$ dimerization using TR-FRET technology.}

(A) COS-7 cells were transiently transfected with plasmids encoding epitope-tagged 5- $\mathrm{HT}_{4} \mathrm{R}(250$ $\mathrm{ng} / 10^{7}$ cells $)$ and/or $\mathrm{GABA}_{\mathrm{B}} \mathrm{R}\left(1,000 \mathrm{ng} / 10^{7}\right.$ cells $)$. Cell surface expression of $5-\mathrm{HT}_{4} \mathrm{R}$ and $\mathrm{GABA}_{\mathrm{B}} \mathrm{R}$ expressed alone or in combination was assessed by ELISA using anti-HA (in white) or anti-FLAG (in black) antibodies in non-permeabilized, transfected cells as described in (Barthet et al., 2005). GB 1 : $\mathrm{GABA}_{\mathrm{B} 1} \mathrm{R} ; \mathrm{GB}_{2}$ : GABA $\mathrm{B}_{2} \mathrm{R}$. (B) TR-FRET between donor and acceptor fluorophore-labeled antibodies directed against the HA and FLAG tags, respectively, placed at the N-terminus of 5-HT 4 R and $\mathrm{GABA}_{B} \mathrm{R}$ as exemplified underneath the graph. Tagged-GABAB receptor subunits $\mathrm{GB}_{1}$ and $\mathrm{GB}_{2}$ were used as a positive control of constitutive dimerization. (C) Saturation FRET experiments. A constant amount of WT HA-5- $\mathrm{HT}_{4} \mathrm{R}$ (donor) was co-expressed with increasing amounts of FLAGtagged WT 5-HT 4 R or $\mathrm{GB}_{2}$ (acceptors). The FRET signal was plotted as a function of cell surface expression of the FLAG-tagged receptors determined by ELISA. (D) Competition FRET experiments. A constant amount of WT HA-5-HT 4 R and FLAG-5-HT 4 R was expressed and the FRET corresponding to their association was determined in the presence of increasing amounts of Myctagged GPCRs belonging to different classes. The FRET signal was plotted as a function of cell surface expression of the Myc-tagged receptors determined by ELISA. Challenger GPCRs: $5-\mathrm{HT}_{7} \mathrm{R}$ and 5-HT 4 R: serotonin receptor subtypes 7 and 4 , respectively; $\beta_{2}-\mathrm{AR}$ : $\beta_{2}$-adrenergic receptor; $\mathrm{GABA}_{\mathrm{B} 2} \mathrm{R}$ : subunit of the $\mathrm{GABA}$ B receptor that reaches the cell surface alone $\left(\mathrm{GB}_{2}\right)$. 


\section{References}

Bakker, R. A., Dees, G., Carrillo, J. J., Booth, R. G., Lopez-Gimenez, J. F., Milligan, G., et al. (2004). Domain swapping in the human histamine H1 receptor. J Pharmacol Exp Ther, 311(1), 131138. doi: $10.1124 /$ jpet.104.067041

Ballesteros, J. A., \& Weinstein, H. (1995). [19] Integrated methods for the construction of threedimensional models and computational probing of structure-function relations in G proteincoupled receptors. Methods in neurosciences, 25, 366-428.

Barnes, N. M., \& Sharp, T. (1999). A review of central 5-HT receptors and their function. Neuropharmacology, 38(8), 1083-1152.

Barthet, G., Gaven, F., Framery, B., Shinjo, K., Nakamura, T., Claeysen, S., et al. (2005). Uncoupling and endocytosis of 5-hydroxytryptamine 4 receptors. Distinct molecular events with different GRK2 requirements. J Biol Chem, 280(30), 27924-27934.

Berger, M., Gray, J. A., \& Roth, B. L. (2009). The expanded biology of serotonin. Annu Rev Med, 60, 355-366. doi: 10.1146/annurev.med.60.042307.110802

Berthouze, M., Ayoub, M., Russo, O., Rivail, L., Sicsic, S., Fischmeister, R., et al. (2005). Constitutive dimerization of human serotonin 5-HT4 receptors in living cells. FEBS Lett, 579(14), 2973-2980.

Berthouze, M., Rivail, L., Lucas, A., Ayoub, M. A., Russo, O., Sicsic, S., et al. (2007). Two transmembrane Cys residues are involved in 5-HT4 receptor dimerization. Biochem Biophys Res Commun, 356(3), 642-647.

Bockaert, J., Claeysen, S., Becamel, C., Dumuis, A., \& Marin, P. (2006). Neuronal 5-HT metabotropic receptors: fine-tuning of their structure, signaling, and roles in synaptic modulation. Cell Tissue Res, 326(2), 553-572. doi: 10.1007/s00441-006-0286-1

Bockaert, J., Claeysen, S., Compan, V., \& Dumuis, A. (2011). 5-HT(4) receptors, a place in the sun: act two. Curr Opin Pharmacol, 11(1), 87-93. doi: 10.1016/j.coph.2011.01.012 
Claeysen, S., Joubert, L., Sebben, M., Bockaert, J., \& Dumuis, A. (2003). A single mutation in the 5HT4 receptor (5-HT4-R D100(3.32)A) generates a Gs-coupled receptor activated exclusively by synthetic ligands (RASSL). J Biol Chem, 278(2), 699-702.

Claeysen, S., Sebben, M., Becamel, C., Bockaert, J., \& Dumuis, A. (1999). Novel brain-specific 5HT4 receptor splice variants show marked constitutive activity: role of the C-terminal intracellular domain. Mol Pharmacol, 55(5), 910-920.

Claeysen, S., Sebben, M., Journot, L., Bockaert, J., \& Dumuis, A. (1996). Cloning, expression and pharmacology of the mouse 5-HT(4L) receptor. FEBS Lett, 398(1), 19-25.

Comps-Agrar, L., Maurel, D., Rondard, P., Pin, J. P., Trinquet, E., \& Prezeau, L. (2011). Cell-surface protein-protein interaction analysis with time-resolved FRET and snap-tag technologies: application to G protein-coupled receptor oligomerization. Methods Mol Biol, 756, 201-214. doi: 10.1007/978-1-61779-160-4_10

Conklin, B. R., Hsiao, E. C., Claeysen, S., Dumuis, A., Srinivasan, S., Forsayeth, J. R., et al. (2008). Engineering GPCR signaling pathways with RASSLs. Nat Methods, 5(8), 673-678.

Dumuis, A., Bouhelal, R., Sebben, M., Cory, R., \& Bockaert, J. (1988). A nonclassical 5hydroxytryptamine receptor positively coupled with adenylate cyclase in the central nervous system. Mol Pharmacol, 34(6), 880-887.

Gorinski, N., Kowalsman, N., Renner, U., Wirth, A., Reinartz, M. T., Seifert, R., et al. (2012). Computational and experimental analysis of the transmembrane domain $4 / 5$ dimerization interface of the serotonin 5-HT(1A) receptor. Mol Pharmacol, 82(3), 448-463. doi: 10.1124/mol.112.079137

Herrick-Davis, K., Grinde, E., Harrigan, T. J., \& Mazurkiewicz, J. E. (2005). Inhibition of serotonin 5hydroxytryptamine2c receptor function through heterodimerization: receptor dimers bind two molecules of ligand and one G-protein. J Biol Chem, 280(48), 40144-40151.

Herrick-Davis, K., Grinde, E., \& Mazurkiewicz, J. E. (2004). Biochemical and biophysical characterization of serotonin 5-HT2C receptor homodimers on the plasma membrane of living cells. Biochemistry, 43(44), 13963-13971. doi: 10.1021/bi048398p 
Kristiansen, K., Kroeze, W. K., Willins, D. L., Gelber, E. I., Savage, J. E., Glennon, R. A., et al. (2000). A highly conserved aspartic acid (Asp-155) anchors the terminal amine moiety of tryptamines and is involved in membrane targeting of the 5-HT(2A) serotonin receptor but does not participate in activation via a "salt-bridge disruption" mechanism. J Pharmacol Exp Ther, 293(3), 735-746.

Lee, S. P., Xie, Z., Varghese, G., Nguyen, T., O'Dowd, B. F., \& George, S. R. (2000). Oligomerization of dopamine and serotonin receptors. Neuropsychopharmacology, 23(4 Suppl), S32-40. doi: $10.1016 / \mathrm{S} 0893-133 \mathrm{X}(00) 00155-\mathrm{X}$

Lukasiewicz, S., Faron-Gorecka, A., Kedracka-Krok, S., \& Dziedzicka-Wasylewska, M. (2011). Effect of clozapine on the dimerization of serotonin 5-HT(2A) receptor and its genetic variant 5-HT(2A)H425Y with dopamine D(2) receptor. Eur J Pharmacol, 659(2-3), 114-123. doi: 10.1016/j.ejphar.2011.03.038

Maurel, D., Kniazeff, J., Mathis, G., Trinquet, E., Pin, J. P., \& Ansanay, H. (2004). Cell surface detection of membrane protein interaction with homogeneous time-resolved fluorescence resonance energy transfer technology. Anal Biochem, 329(2), 253-262.

Millan, M. J., Marin, P., Bockaert, J., \& Mannoury la Cour, C. (2008). Signaling at G-protein-coupled serotonin receptors: recent advances and future research directions. Trends Pharmacol Sci, 29(9), 454-464. doi: 10.1016/j.tips.2008.06.007

Pellissier, L. P., Barthet, G., Gaven, F., Cassier, E., Trinquet, E., Pin, J. P., et al. (2011). G protein activation by serotonin type 4 receptor dimers: evidence that turning on two protomers is more efficient. J Biol Chem, 286(12), 9985-9997. doi: 10.1074/jbc.M110.201939

Renner, U., Zeug, A., Woehler, A., Niebert, M., Dityatev, A., Dityateva, G., et al. (2012).

Heterodimerization of serotonin receptors 5-HT1A and 5-HT7 differentially regulates receptor signalling and trafficking. J Cell Sci, 125(Pt 10), 2486-2499. doi: 10.1242/jcs.101337

Srinivasan, S., Santiago, P., Lubrano, C., Vaisse, C., \& Conklin, B. R. (2007). Engineering the melanocortin-4 receptor to control constitutive and ligand-mediated G(S) signaling in vivo. PLoS One, 2(7), e668. doi: 10.1371/journal.pone.0000668 
Strader, C. D., Gaffney, T., Sugg, E. E., Candelore, M. R., Keys, R., Patchett, A. A., et al. (1991). Allele-specific activation of genetically engineered receptors. J Biol Chem, 266(1), 5-8. 
A

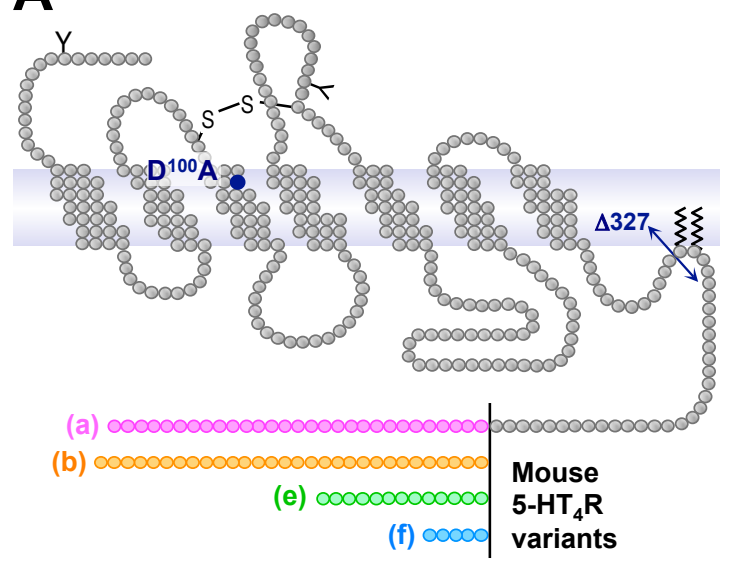

B

- $D^{100} A$

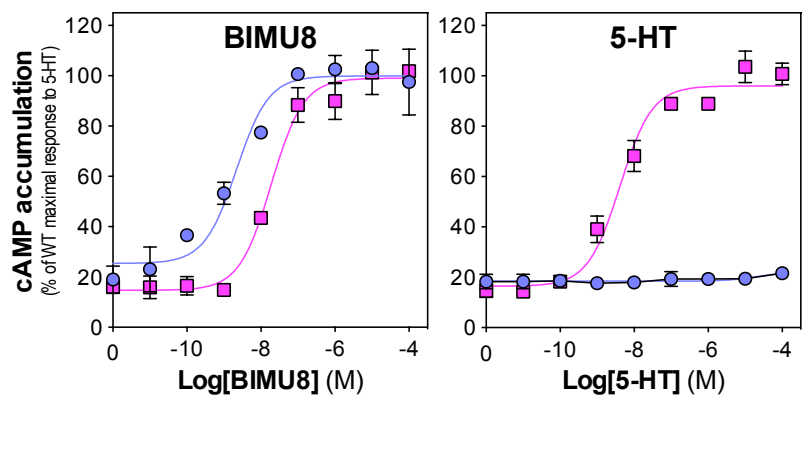

Figure 1 

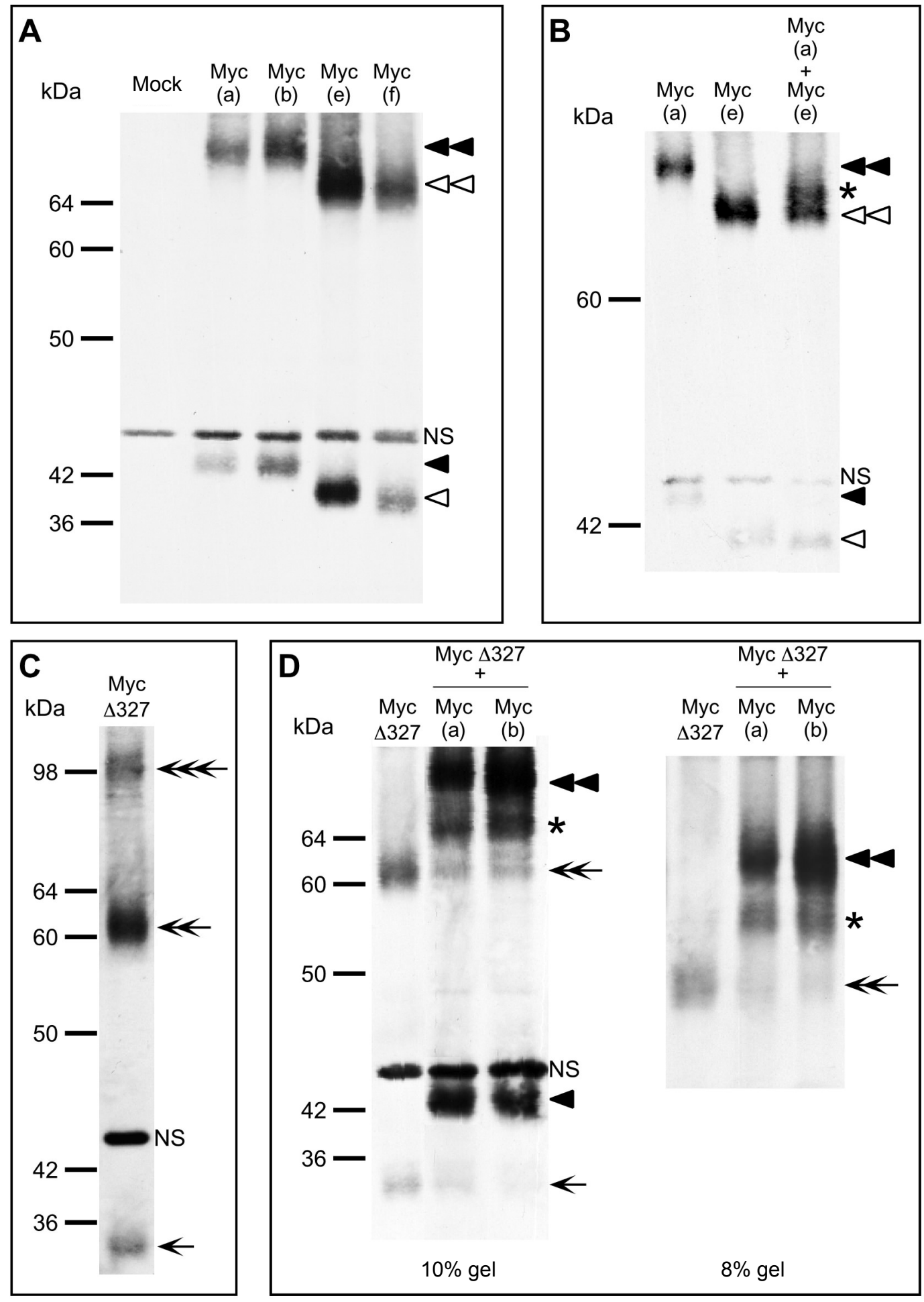

Figure 2 


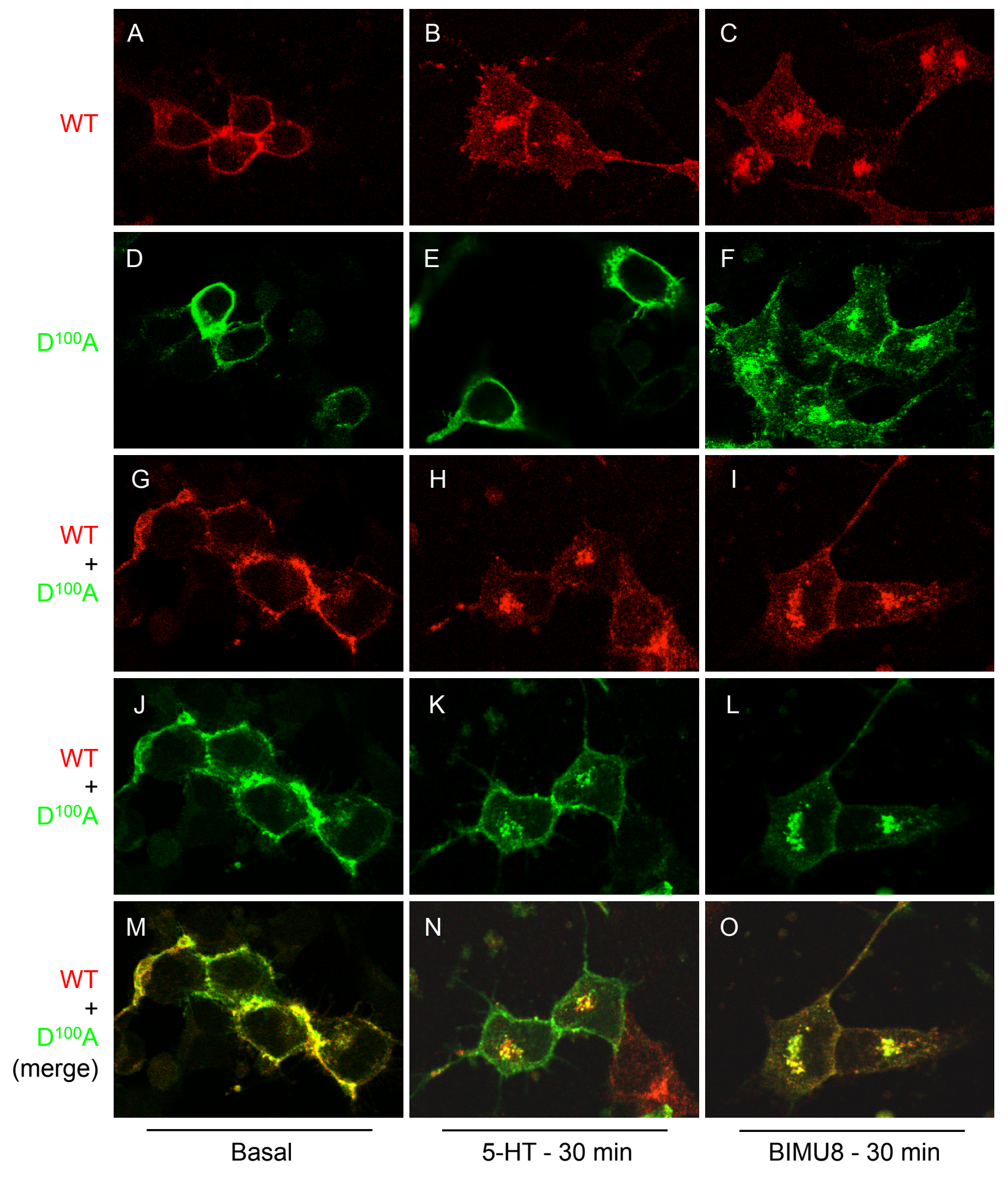

Figure 3 
A
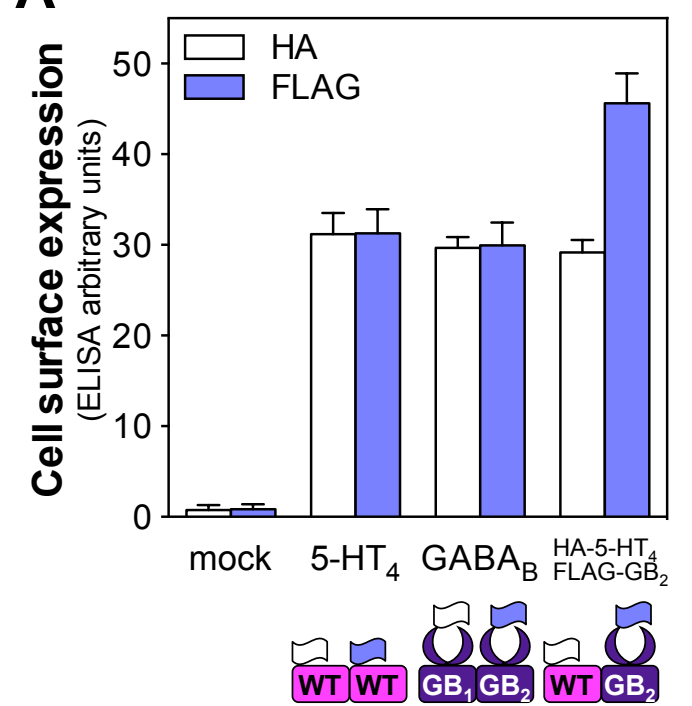

B

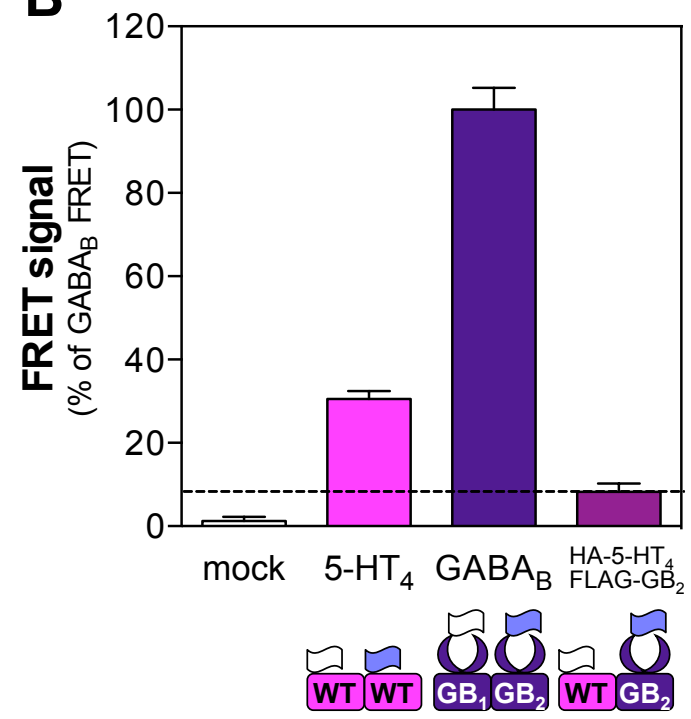

D

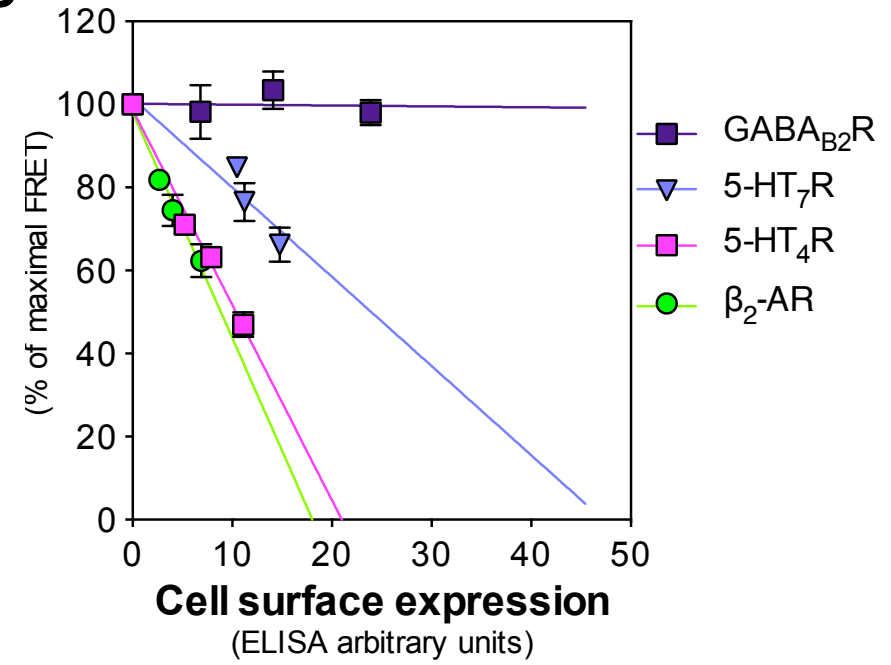

Figure 4 